JOSIP MIHALJEVIĆ, PhD, Research Fellow

Croatian Institute of History

Zagreb, Republic of Croatia

josip@isp.hr

GORAN MILJAN, PhD, Researcher

Hugo Valentin-centrum, Uppsala University

Uppsala, Kingdom of Sweden

goran.miljan@valentin.uu.se

naučna kritika / scholarly polemic

primljeno / received: 11.3. 2021.

prihvaćeno / accepted: 19. 5. 2021.

https://doi.org/10.29362/ist20veka.2021.2.mih.479-500

\title{
"HUMANIST" MARXISM AND THE COMMUNIST REGIME WITH "SPARKLES" OF TOTALITARIANISM: THE YUGOSLAV COMMUNIST TOTALITARIAN EXPERIMENT (RESPONSE TO FLERE AND KLANJŠEK)
}

ABSTRACT: This paper is a response to the article "What Typological Appellation is Suitable for Tito's Yugoslavia" published by Sergej Flere and Rudi Klanjšek in Istorija 20. veka, in which the two authors reflected on our article "Was Tito's Yugoslavia Not Totalitarian?" Instead of engaging in an open academic debate based on arguments and empirical data, Flere and Klanjšsek concentrate their approach on detecting textual mistakes, which they then use as proof of our superficial and counter-factual approach. In this article, we focus on providing arguments and empirical data which demonstrate that Flere and Klanjšek's arguments as well as their newly introduced views on the subject hold little merit. In fact, we have shown that their attempt to discredit us is nothing but an example of how an academic debate can turn into a blatant non-academic debate when scholarly based approach, academic professionalism and facts are run over by sentiment.

KEYWORDS: Totalitarianism, Yugoslavia, Communism, Federalism, Josip Broz Tito, Individual

\section{The intention of our article}

This paper is a response to the article: What Typological Appellation is Suitable for Tito's Yugoslavia: Response to Mihaljević and Miljan, published by Sergej Flere and Rudi Klanjšek in Istorija 20. veka, 38, no. 2, (2020), 231-244. We are 
sorry to see that the two authors read our earlier response ${ }^{1}$ to their previously published article ${ }^{2}$ as some sort of attack either on them personally or on their academic merits or research. This was certainly not our intention nor do we wish to engage in such activities. Some sentences may sound harsh and perhaps could have been structured differently, but we wish to emphasize that there was no intent to discredit the authors. On the contrary, we consider their article to be of value in future discussions regarding the nature of the communist regime in Tito's Yugoslavia.

When writing our response to Flere and Klanjšek's article on the question of totalitarianism in Tito's Yugoslavia, we set up two goals: (i) to show that the complexity of the political system established in Yugoslavia could not and should not be explained through a single, sixty-five-year-old model, but rather by engaging into a thorough contemporary conceptual understanding and questioning of the nature of this regime with regard to the validity and applicability of the concept of totalitarianism; (ii) we wanted to show that some of their arguments could easily be refuted by empirical data.

For this, we have chosen a highly prominent author, David D. Roberts and his book from $2006,{ }^{3}$ to show that conceptual simplification and neglect of a broader range of debates can lead to questionable evaluations and conclusions. Instead of providing answers, Flere and Klanjšek pose more questions from a theoretical and empirical point of view. In their original article, the two authors limit their conceptual understanding of totalitarianism to works written until the end of the 1970s, which is problematic having in mind the number of publications written on the topic during the post-' 89 period. Certainly, the authors are free to use whichever definition, model, or theoretical approach they wish but should nevertheless reflect on the state-of-the-art literature in the field to justify their choice. Otherwise, the reader gets the feeling, as we did, that something was missing and that their choice seemed like an easy way out. And while this is a legitimate choice to make, it leaves an open space for criticism; a criticism not based on the "dubious nature" 4 as the authors are convinced, but instead on an aspiration to move this often emotional, and to some even personal, topic into the field of open, academic discussion. Unfortunately, Flere and Klanjšek seem incapable of maintaining their level of discussion on an academic level. Unlike them, we do not wish to enter our personal feelings into this debate. To do so would serve only to distract the reader from the main issue, and that is that their analysis is based on an obsolete model of totalitarianism, which consequently renders their arguments on the role of federalism, Tito, the repressive apparatus, or that of an individual within the Yugoslav society, to be easily refuted.

\footnotetext{
1 Josip Mihaljević and Goran Miljan, “Was Tito’s Yugoslavia Not Totalitarian?”, Istorija 20. veka, 38, br. 1, (2020), 223-248.

${ }^{2}$ Sergej Flere and Rudi Klanjšek, "Was Tito's Yugoslavia Totalitarian?" Communist and PostCommunist Studies, 47, (2014), 237-245.

${ }^{3}$ David D. Roberts, The Totalitarian Experiment in Twentieth Century Europe: Understanding the Poverty of Great Politics (New York - London: Routledge, 2006).

${ }^{4}$ Sergej Flere and Rudi Klanjšek, "What Typological Appellation is Suitable for Tito's Yugoslavia: Response to Mihaljević and Miljan”, Istorija 20. veka, 38, br. 2 (2020), 232.
} 
Let us start at looking into how the authors seem to contradict themselves. In their original article, they state that "The sole aim is to provide insight into whether the designation 'totalitarian' is appropriate for Yugoslavia as ruled by Tito and the order set up under him in this period." "Further on, they claim that to avoid difficulties arising from the complexities surrounding the concept of totalitarianism, they focus "on a more straightforward definition of totalitarianism: the one introduced by Friedrich and Brzezinski." In their conclusion, the authors say the following: "The current paper has tried to address the issue of whether Yugoslavia was a totalitarian state. Since it is often a matter of dispute what the terms 'totalitarianism' or 'totalitarian regime' mean and represent, the concept used in the study was the one advanced in the classical study by Friedrich and Brzezinski as it seemed most operationalizable, that is, it most clearly expressed the dimensionality and character of said regime." ${ }^{, 7}$ However, in their reaction to our criticism of using Friedrich and Brzezinski's model, the authors stated that they "did not adhere exclusively to the definition of Friedrich and Brzezinski." "Thus, in their original paper, they "focus on" and "use" Friedrich and Brzezinski's concept, only to later claim that they do not adhere exclusively to this model. Considering that in their original paper, under section 2 entitled Totalitarianism, they do not discuss any other model of totalitarianism, the question which needs to be addressed here is: which model or concept of totalitarianism do Flere and Klanjšek adhere to? This is, of course, a rhetorical question, since there is no doubt that in their analysis, they "focus on" and "use" the model of Friedrich and Brzezinski against which they juxtapose the structure and developments that occurred in Tito's Yugoslavia.

Furthermore, in their response, Flere and Klanjšek make numerous statements that have nothing to do with our arguments or what we wished to say. For clarification, we will reflect on some from a multitude of such examples. Flere and Klanjšek claim that we aim to establish a new methodology by saying that "instead of the 'active' and 'passive' freedom known in political philosophy, they [Mihaljević and Miljan] speak of a 'negative' and 'positive' freedom, without explaining how this typology relates to the classical knowledge on freedom and why it should be considered superior." "To simplify: this is not true. What we wrote in our article was this: "Even if certain 'freedoms' were allowed, these do not connote the classical, western liberal meaning of freedom. In our opinion, they mean passive freedom, the freedom given by the elite, controlled by the elite, and if necessary, taken away by the elite if it feels that their totalitarian experiment is in danger."10 We never mentioned "active" or "passive" freedom, but quite the opposite. As shown in the quote above, we use the term "passive" freedom.

\footnotetext{
${ }^{5}$ S. Flere and R. Klanjšek, "Was Tito's Yugoslavia Totalitarian?”, 238.

${ }^{6}$ Ibid.

${ }^{7}$ Ibid., 243.

${ }^{8}$ S. Flere and R. Klanjšek, "What Typological Appellation is Suitable for Tito's Yugoslavia", 232.

${ }^{9}$ Ibid., 240.

${ }^{10}$ J. Mihaljević and G. Miljan, “Was Tito’s Yugoslavia Not Totalitarian?”, 227.
} 
In order to determine the pattern of thought in Flere and Klanjšek's attempt to prove that we were superficial, counter-factual, and whatnot, it suffices to take their statement from page 241: "Mihaljević and Miljan also make a rather quick and unsubstantiated judgment of Tito as an apex of totalitarian power." 11 In our response, we aimed to show the complexities of Tito's role and the power which he undoubtedly held in Yugoslavia. However, Flere and Klanjšek argue that Tito did not hold power to remove, initiate policies, or that he had the final word in this communist regime since such conclusion are "quick and unsubstantiated." This is an interesting statement, especially in view of the fact that the two authors failed to adhere to the same criteria in their writing: in their original article they stated that Tito's words "cannot be considered those of a totalitarian dictator, inspired by an ideologically 'chiliastic' mission, but the words of a concerned political leader."12 Thus, while our discussion of Tito is taken as "quick and unsubstantiated", their claim that Tito was neither a "totalitarian dictator", nor that he spoke as one, is to be taken as substantiated and based on their lengthy (sic!) analysis of Tito's leadership, charisma, and political role. Their lengthy analysis concluding that Tito is nothing more but a "concerned political leader", is based on a single sentence that Tito gave in 1962 during the meeting of the League of Communists of Yugoslavia (LCY) Executive. Furthermore, their usage of the term "totalitarian dictator" is, well, baffling. They neither elaborate on, nor provide any reflection on what the term itself is supposed to designate. For what reason Flere and Klanjšek felt that this was the appropriate term to use remains a puzzle. We are left to ponder what the term "totalitarian dictator" means. Is it in any way different from a "normal" dictator? Does it mean that Tito was "merely" a dictator, an "enlightened" dictator, or perhaps a "humanist" dictator?

\section{Introducing New Arguments - Adding Little Value}

In their endeavor to prove that after the mid-1960s the term totalitarian is not suitable to define communist ideology and regime in Tito's Yugoslavia, Flere and Klanjšek saw it essential to introduce discussion on consociation which was absent in their original article. Could it be that they thought that their original article required an update, or further clarifications, considering the amount of newly introduced topics? Flere and Klanjšek state that: "it becomes clear that the SFRY expressed all of the features of an adjustment consociation," and that: "the Yugoslav political system can be nominated as an authoritarian consociation from the mid-1960s on", as well as that Yugoslavia could be looked upon as a "predetermined consociation". ${ }^{13}$

${ }^{11}$ S. Flere and R. Klanjšek, "What Typological Appellation is Suitable for Tito's Yugoslavia”, 241.

${ }^{12}$ S. Flere and R. Klanjšek, "Was Tito's Yugoslavia Totalitarian?”, 239.

${ }^{13}$ S. Flere and R. Klanjšek, "What Typological Appellation is Suitable for Tito's Yugoslavia", 233-234. 
By introducing this new concept, Flere and Klanjšek fail to reflect on the key issues raised in our article and move us back to the same problem that we addressed in our initial article. Namely, the arguments they enumerate in their support for consociation could make sense were it not for one irrefutable fact: all these different interest groups, as they refer to them, belonged to one political organization - the LCY, headed by Josip Broz Tito. Within the LCY, the decision-making processes were based on Lenin's principle of democratic centralism, i.e., the obligation of responsibility and discipline of lower political structures and bodies regarding the decisions taken by the central bodies of the LCY. Therefore, decisions and guidelines from the highest level of the party were considered as final and were to be accepted and implemented by the lower-level political structures, including the leadership on the level of the federal republics. The arguments they put forward in order to prove that this was a "malfunctioning consociation" only contribute to the fact that internal disputes and conflicts within the party emerged. We agree with Flere and Klanjšek's statement that: "There is no doubt that consociational decision making, [...] worked centrifugally toward an ever greater awareness of the interests of the Yugoslav republics, objective or not, where the commonalities slowly faded from their vista." ${ }^{15}$ However, this tells us very little about changes or ruptures within the communist leadership as to the ideas and/or goals on how to structure and control Yugoslav society. Actually, the communist leaderships and organizations of the republics were expected, and when necessary even forced to implement centrally decreed policies. When particular (i.e. republic) interests, in other words, the interests of the party leaders of the federal republics collided with the interest and policies of the LCY leadership, the (usual) solution was expulsion from the Party. Flere and Klanjšek state the same in their article: "[...] he [Tito] dealt with it in the only way he knew: by expelling those who were too loud in promoting their individual republic interests and openly invoking nationalism." ${ }^{.16}$ Indeed, Tito dealt with it in the true manner of a dictator, perhaps even a "totalitarian dictator," if we are to use the term coined by Flere and Klanjšek.

In their further argument about Yugoslavia being a consociation, Flere and Klanjšek state that "in Slovenia, there were no political prisoners by the end of the 1970s. This, of course, is not about federal decision making, but about the autonomy of the entities." ${ }^{17}$ Here, they touched upon one of the critical characteristics of Tito's Yugoslavia, which concerns the criminal prosecution of opponents of the political system and the regime. According to 1976 data from the federal secretariat of internal affairs, in the mid-1970's around 1,500 persons a year were indicted for political crimes, while another 5,500 were accused of political transgressions. ${ }^{18}$

\footnotetext{
${ }^{14}$ Ibid., 234.

${ }^{15}$ Ibid., 235.

${ }^{16}$ Ibid.

${ }^{17}$ Ibid., 235-236.

${ }^{18}$ Hrvatski državni arhiv (HR-HDA), fond 1220, Centralni komitet Saveza komunista Hrvatske (CK SKH), Predsjednik CK SKH, Političko-sigurnosna situacija u SRH i SFRJ, box 3, 01-1,
} 
When looking at statistical data, there were differences on the level of the federal republics. According to figures for 1976, out of the total of 1,772 criminal charges in the Socialist Federal Republic of Yugoslavia (SFRY): Bosnia-Herzegovina had around 34\% (608) and Croatia 29\% (512), while the other republics and provinces had a significantly lower number: Serbia proper (without the Socialist Autonomous Province of Vojvodina and the Socialist Autonomous Province of Kosovo) had 14\% (249), Vojvodina 8\% (151), Kosovo 2\% (36), Slovenia 9\% (164), Montenegro $2 \%$ (38), Macedonia 1\% (24). For example, in Croatia, in 1976, out of 512 criminal charges, 293 (57\%) ended with a court ruling. The facts show that the number of political prosecutions and prisoners was lower in Slovenia than in Croatia, BosniaHerzegovina, or Serbia. However, contrary to what Flere and Klanjšek argue, there were political prisoners during the late 1970s and early 1980s in SR Slovenia. As Štih, Simoniti, and Vodopivec argue: "Slovenia's political convicts in the 1970s and early 1980s were largely prosecuted and imprisoned for written and 'speech crimes' or for handling illicit books and writings."19 A case in point is that of Franz Miklavčič. He was charged with "hostile propaganda", "endangering Yugoslavia's territorial unity", and the "disclosure of official secrets." He received a prison sentence in 1976, with his case taken up by Amnesty International. ${ }^{20}$ Even though socialist Yugoslavia was and still is widely considered as a somewhat "softer" variant of communism, according to the documents gathered and published by Amnesty International in 1990, the number of political prisoners remained one of the highest among the communist regimes in Europe. ${ }^{21}$

\section{Who Wrote What?}

Flere and Klanjšek suggest that we have accused them of saying things that they did not say. They write: "it seems that they completely missed the fact that we were not out to prove whether the Yugoslav system was or was never totalitarian. We clearly wrote that we allowed it to be totalitarian until the mid-

strogo povjerljivo 1976, „Procena neprijateljskih snaga koje deluju protiv SFRJ - peta i šesta kolona”, Beograd, 15. 11. 1976, 16.

${ }^{19}$ Peter Štih, Vasko Simoniti and Peter Vodopivec, Slovene History: Society - Politics - Culture (Ljubljana: Inštitut za novejšo zgodovino, 2008), 491, http://hdl.handle.net/11686/2250 (accessed 14. 2. 2021).

20 "In 1976, Franc Miklavčič, a Slovenian judge and former Partisan, was tried on charges of 'hostile propaganda' based on an article he wrote that appeared in a journal published in Trieste, Italy. In the article he defended previous statements in the journal by Roman Catholic poet Edvard Kocbek, also a former partisan. (...). Franc Miklavčič was also charged with 'endangering the territorial unity of Yugoslavia' for political views he expressed in his personal (unpublished) diary, found by the police in a friend's flat; a third charge was for 'disclosure of official secrets' - for having borrowed from a law court library a magazine stamped 'for internal use only' which he allowed a friend in the legal profession to copy. He was sentenced to five years and eight months' in prison, later reduced to two and a half years." Yugoslavia: Prisoners of Conscience: Amnesty International Report (London: Amnesty International Publications, 1981), 14.

${ }^{21}$ See: Amnesty International Report 1990 (London: Amnesty International Publications, 1990), 263. 
1960s." ${ }^{22}$ It is incorrect to make such claims, since this was precisely the aspect of their argument to which we reflected in length and depth to argue, that contrary to their beliefs, Tito's Yugoslavia did not stop being totalitarian from the mid-1960s. ${ }^{23}$ The same reasoning can be applied to their claim on page 241: "Therefore, we cannot accept the 'breakdown of totalitarianism' as the best explanation for the downfall of Yugoslavia." ${ }^{24}$ Here they are doing the exact same thing they accuse us of doing. We never discussed the reasons behind the breakup of socialist Yugoslavia, nor was this the topic of the article itself, a topic, which due to its complexity, would require an in-depth analysis that goes beyond the scope and space of our article. We discussed the dynamics of totalitarianism and its demise without attempting to explain the reasons behind the breakup of socialist Yugoslavia. In their continuation of applying that which they criticize us for, Flere and Klanjšek, for lack of any arguments, claim that we "do not recognize nationalism in Yugoslavia at all: "[nationalism] is something communist rulers used primarily to define enemies." ${ }^{25}$ This statement is not valid, and any well-intentioned reader can easily see this. We never denied either the existence or the role that nationalism played in socialist Yugoslavia. Our article's focus was not on Yugoslavia's breakup but the claims put forward by Flere and Klanjšek regarding the question of totalitarianism in Tito's Yugoslavia. There is no doubt that the national question played a significant role in the Yugoslavia's breakup, which we did acknowledge in our paper on page 235, and which was perhaps one of the key factors. The quote they provide is part of a longer sentence from a footnote in which we clarified the question of terminology and various meanings that some terms can have. We wrote this: "We should be very careful when we use the term 'national.' In the Croatian and Serbian languages, the words 'people's' (narodno) and 'national' (nacionalno) are not synonymous. [Moreover, at the time of the existence of Tito's Yugoslavia, in some contexts, the term national (nacionalno) could have been given negative connotations. The adjective nationalistic (nacionalistički) was derived from this term, and was the adjective which communist rulers used primarily to define enemies of Yugoslav socialism and of their idea of 'brotherhood and unity $\left.{ }^{6}\right]^{\prime 26}$ Thus, we never discussed the national question as Flere and Klanjšek would have their readers believe, nor did we engage in a discussion on Yugoslavia's breakup, as they would also like to have their readers believe.

The same approach is taken when Flere and Klanjšek claim that: "Mihaljević and Miljan are flat out wrong on some elementary facts. For example, on page 240 they claim that Janković and Čolaković described 'the early seventies' in a book published in 1964. [...] In fact, Mihaljević and Miljan commit gross negligence in their referencing, all in what seems to be their enthusiastic

\footnotetext{
${ }^{22}$ S. Flere and R. Klanjšek, "What Typological Appellation is Suitable for Tito's Yugoslavia," 232.

${ }^{23}$ J. Mihaljević and G. Miljan, "Was Tito's Yugoslavia Not Totalitarian?", from page 228 onwards.

${ }^{24}$ S. Flere and R. Klanjšek, "What Typological Appellation is Suitable for Tito's Yugoslavia," 241.

${ }^{25}$ Ibid., 241.

${ }^{26}$ J. Mihaljević and G. Miljan, “Was Tito’s Yugoslavia Not Totalitarian?”, 229.
} 
endeavor to prove their 'point.," ${ }^{27}$ What we wrote was the following: "The communist government in Yugoslavia, or the part that prevailed in the early 1970s, felt the need to "completely suppress the view that the press and the radio are isolated and independent political factors, which create and express public opinion." ${ }^{28}$ Here we do provide a reference to Janković and Čolaković's 1964 book on the history of the LCY where they expressed such views, which we claim were later accepted by the "The communist government in Yugoslavia, or the part that prevailed in the early 1970s." The point of this was that the communist leadership held the same views in the 1970s as those emphasized by Janković and Čolaković in their 1964 book. Herein lies the misunderstanding of what we wrote, not the negligence. This statement by Flere and Klanjšek only shows the length the two authors are willing to go in their attempt to defend the indefensible and which, once again, has nothing to do with the topic in question. However, by engaging in such accusations, as though it would somewhat strengthen the weaknesses of their analysis, they reveal their lack of professionalism as well as scholarly-based approach. Perhaps this allows us also to use the same unsubstantiated criticism. For example, we could state that at least one of them actually possesses the ability of time travel, since he is capable of conducting interviews in $1918 .{ }^{29}$ Perplexing, indeed. Or is it gross negligence in referencing from their side?

\section{On the Role of the State Security Service}

This further supports our claim that what they are trying to do throughout their response to our criticism is the pattern of "accusation in a mirror." Another example can be found in their response regarding the role and functionality of the Yugoslav State Security Service (Služba državne bezbednosti) (SDB). Flere and Klanjšek claim that we stated that the "security services in Yugoslavia were integrated faultlessly until the very end" and that they functioned "within a perfect hierarchical, smoothly functioning system". ${ }^{30}$ Such a statement is not valid, nor did we write this. In our article, we reflected upon their claim that there was a "lack of cooperation and coordination" when it comes to the SDB. Furthermore, we argued that even if there were differences or disputes, this meant very little or nothing for an individual who could care less which branch or division of Tito's regime the repression came from. Important to stress here is the fact that Flere and Klanjšek show a lack of knowledge on the question of individuals and their position within the communist totalitarian experiment. They fail to touch upon this issue altogether.

The key issue missed by Flere and Klanjšek is that the Yugoslav State Security, despite its re-organization after 1966, remained a unified organization.

\footnotetext{
${ }^{27}$ S. Flere and R. Klanjšek, "What Typological Appellation is Suitable for Tito's Yugoslavia", 239-240.

${ }^{28}$ J. Mihaljević and G. Miljan, "Was Tito’s Yugoslavia Not Totalitarian?”, 240.

${ }^{29}$ S. Flere and R. Klanjšek, "What Typological Appellation is Suitable for Tito's Yugoslavia", 237.

${ }^{30}$ Ibid., 236.
} 
Just as the LCY was an organization with its lower (republic, municipal and other local) branches, the same can be stated for the SDB. We never said nor implied that the SDB was a monolithic, smoothly functioning system, because it was not. However, it was neither pluralistic nor were its republic and local branches independent from the federal level and the political power of the LCY, as Flere and Klanjšek argue. In fact, in June of 1972, socialist Yugoslavia's presidency decided to establish a body called the Council for State Security (Savet za državnu bezbednost), whose task was to supervise the Yugoslav system of state security. In the spring of 1975, its authorities were expanded and it received a new name: The Federal Council for the Protection of Constitutional Order (Savezni savet za zaštitu ustavnog poretka, SSZUP). Its prerogatives ranged from "directing the work of the organs of security" (organi bezbednosti) as well as "the coordination of measures and security actions which the Council deems to be of special interest for the country's security." 31 The Federal Council was also given the final say in deciding "which security organ shall carry the task in the case when its superiors could not reach such consent." ${ }^{2}$ A case in point is the event from 1977 when Vladimir Bakarić, chairman of the SSZUP, had to intervene and summon to a meeting the representatives of the republic secretariat of internal affairs of the SR of Croatia and the secretariat of internal affairs of the city of Zagreb in order to resolve their dispute regarding jurisdiction. Criticism put forward by Bakarić against Zvonimir Jurišić, the president of the Council for the Protection of Constitutional Order of the Presidency of the SR Croatia, was ultimately accepted not only by Jurišić himself, but also by Zlatko Uzelac, the minister (sekretar) of internal affairs of the SR Croatia. ${ }^{33}$ Furthermore, the extent of the federal political influence on the SDB was acknowledged in 1999 by Dragoljub Krnić, who served as chief of the SDB center of the city of Osijek from 1972 through 1989, where he stated that "the SDB took no steps without the approval of the political elite." 34 Even though the UDBA (in Serbian: Uprava državne bezbednosti) received a new name after the organizational changes in 1966, its primary function was not changed. The organization remained primarily oriented toward the fight against class enemies. In fact, this was its differentia specifica emphasized by the department heads themselves when they accentuated the difference of their work "from classical, state secret services which de facto do not have this [class] interest." 35

${ }^{31}$ Dino Mujadžević, Bakarić - politička biografija (Zagreb: Hrvatski institut za povijest - Podružnica za povijest Slavonije, Srijema i Baranje, 2011), 311.

${ }^{32}$ Ibid., 312.

${ }^{33}$ HR-HDA, 1220, CK SKH, Predsjednik CK SKH, Sigurnosno-politička situacija u SRH i SFRJ, box 1, 01-1, SP, 1977, „Magnetofonski snimak sastanka održanog 17. 1. 1977. god. u zgradi Sabora SRH“.

${ }^{34}$ Bože Vukušić, „Predgovor: Metodologija rada Udbe na primjeru Vice Vukojevića,“ in: Dosje 240271: Udbin dosje o Vici Vukojeviću, ed. Bruna Esih (Zagreb: Udruga Hrvatski križni put, 2015), XXV.

35 HR-HDA, fond 1561, Služba državne sigurnosti Republičkog sekretarijata za unutrašnje poslove Socijalističke Republike Hrvatske (SDS RSUP SRH), Rad Službe (izvještaji, uputstva, 
While the state's security forces (police, state security, and military) functioned as the party-state's pillars, this in no way implies the state itself was monolithic. As Nielsen states, monolithic ideal-type totalitarianism in the Weberian sense never existed in practice since everyday historical life is much more complex so that even in the toughest, Stalinist version of the party-state, there were tensions, opposite tendencies, and inconsistencies. ${ }^{36}$ Same conflicts, disagreements, and disputes are also detectable within the various levels of the communist rule in Yugoslavia. In the end, perhaps it would be helpful to repeat what we already stated in our original article: "However, even if we fully accept the claims that the state security service was decentralized, that there was no cooperation or coordination [between the federal and the republic branches of the SDB], what did that mean for an individual who lived in this totalitarian experiment?"37

\section{Monetary System}

In their well-established manner of detecting and accentuating minor flaws, or typos in our text and building their criticism and disqualification around them, Flere and Klanjšek continued to do so in the section on the monetary system in Yugoslavia. While we see no issues in agreeing with some of the arguments they put forward, most of what they wrote has nothing to do with what we reflected upon in our article. Their extensive and newly introduced discussion on inflation carries little relevance to our text, where we argued that the Yugoslav monetary system was a unified one. Yes, we are aware that it was a unified system and not a unitarist one. But, Flere and Klanjšek, instead of engaging in the merit of the topic discussed, focus on this one mistake where instead of unified, we said unitarist. Let us clarify: the mistake, which they use for disqualification of the argument, is on page 230 and not on page 220, as they state, showing now their gross negligence in referencing. Furthermore, page 220 does not exist in our article, since it begins on page 223 . As previously said, we typed the term "unified" when translating the article 260 from the 1974 Constitution of the SFRY. And instead of holding strong to this mistake, perhaps the two academics could have stated that they can presume, or would at the very least like to believe, that we made an honest mistake in consideration of our usage of the term unified. But then, they would have to abandon the whole purpose of their response, which seems to be nothing else but an ill-constructed attempt to discredit our arguments and more importantly our irrefutable data. Our arguments are based on the Yugoslav Constitution and laws that stipulate the existence of a unified monetary system. Flere and Klanjšek think that "holding to constitutional provisions is of little

zapisnici, kadrovi), Centri SDS-a: rad službe, „Saradnik i veza SDS-a - izlaganja na seminaru u Centru SDS Zagreb, Zagreb, 1975.“ “šifra 38/5-701, 52.

36 Christian Axboe Nielsen, „Decentralizacija organa unutarnjih poslova u SR Hrvatskoj“, Politička misao, 57, br. 3, (2020), 177.

${ }^{37}$ J. Mihaljević and G. Miljan, “Was Tito's Yugoslavia Not Totalitarian?”, 232. 
help" while arguing for a broader analysis when analyzing the monetary system. ${ }^{38}$ Certainly, such a broader analysis is needed, but we have difficulty believing that the constitution and other legal provisions would be of little help. Especially when considering that constitutional provisions and laws defined and established the monetary system in Tito's Yugoslavia.

\section{The "Legitimacy" of the Communist Rule}

In their response, Flere and Klanjšek also mention legitimacy regarding the communist rule in Yugoslavia. They state: "True, the 1945 election was not fair, but Ramiz Crnišanin, Milovan Đilas, and Vladimir Velebit, insiders in 1945, all opined much later that the support was such that the election would be won throughout Yugoslavia." 39 Considering who the three protagonists of this statement were, their desire to show that communists would have won the elections either way, is questionable, if not outright subjective and exculpating. Nevertheless, Flere and Klanjšek would have their readers believe that what Crnišanin, Đilas, and Velebit stated is to be taken not only for granted but actually as proof of the communist legitimacy to rule.

Another problematic issue with the above statement is how to prove that the regime had legitimacy when there were no free elections? However, real legitimacy can only be proven through free elections, which did not exist in socialist Yugoslavia until the 1990s, by which time the LCY had ceased to exist. Even if one wishes to accept statements made by Crnišanin, Đilas, and Velebit when they speak of 1945, could the same be applied to, say 1958, 1968, 1972, or even 1985 ? Even if we were to take for granted that in 1945, they enjoyed substantial support and were "given" the right to rule, does this mean that they could rule over a long period of 45 years? According to Flere and Klanjšek, yes, they did, and they could. They state on page 239 that "Even as late as 1990, when ethnic entrepreneurship had well drilled through the tissue of Yugoslavia, the vast majority of the populace clung to Yugoslavia (opting for it and against independent republics), with a notable exception in Kosovo and a moderate one in Slovenia." 40 If anything is notable, it is that Flere and Klanjšek seem to have forgotten the topic of the discussion: the legitimacy of the communist rule in Yugoslavia, and not whether its citizens supported the existence of the Yugoslav state or the establishment of independent republics, which are entirely different issues. To talk about the legitimacy of communists in 1990 is impossible, considering that the LCY formally ceased to exist in January of 1990. The communist leadership in all the republics decided to establish new political parties and test their legitimacy in elections, which were, to say the least, devastating for all newly reformed parties, save those in Serbia and Montenegro. ${ }^{41}$

\footnotetext{
${ }^{38}$ S. Flere and R. Klanjšek, "What Typological Appellation is Suitable for Tito's Yugoslavia”, 238.

${ }^{39}$ Ibid.

${ }^{40}$ Ibid., 239.

${ }^{41}$ In Croatia, the communist leadership formed a new political party called the League of Communist of Croatia - Party of Democratic Changes and joined the coalition with the Alliance of
} 
To conclude this section, legitimacy presents a constitutionally determined procedure by which a political system finds its justification in the sense that the rulers communicate with their citizens as political subjects to obtain their recognition of the right to political rule. However, in the case of the LCY and its sacrosanct rule that lasted for almost half-a-century, it is difficult to talk about legitimacy of rule, but rather about auto-legitimization of the party monopoly. ${ }^{42}$

\section{The Issue of Dynamics}

When discussing the need to observe the dynamics of totalitarianism, which we mentioned in our article, Flere and Klanjšek would have their readers believe that we do not show it in our work. In their response, they state: "We clearly listed indications which, taken together, demonstrate that almost no trace of totalitarianism, taken in the accepted political-science meaning, remained after the mid-60s."43

Firstly, this statement shows an exciting twist in Flere and Klanjšek's key argument on totalitarianism. In the abstract of their original article, they clearly state that following the mid-1960s: "Neither other elements of totalitarianism could be found." 44 Thus from the statement that there existed no totalitarianism elements after the mid-1960s, it seems they have modified their original conclusion and now argue that there were "almost" no traces. Are they claiming that there were some

Socialists of Croatia receiving $35 \%$ of the votes and thus losing the election. In Slovenia, the communists changed their name into the League of Communists of Slovenia - Party of Democratic Changes. And while they won substantial votes individually, they won only $17,3 \%$ of the total votes and had to acknowledge defeat. In the Bosnia-Herzegovina election in November of 1990, the League of Communist of Bosnia-Herzegovina - Party of Democratic Changes lost by receiving less than $8 \%$ of the overall votes. That same month, the League of Communist of Macedonia - Party for Democratic Changes won less than $26 \%$ of the votes. As mentioned, the communist managed to stay in power in Serbia. Renaming themselves the Socialist Party of Serbia, they won over $46 \%$ of the votes. The only republic where the communists managed to get absolute majority of votes was Montenegro, where the League of Communists of Montenegro won over $56 \%$ of the votes. For more information on the election results in various republics, see Mirjana Kasapović, „Izborni modeli i politički sustav“, Politička misao, 29, br. 2, (1992), 12-22; Mladen Klemenčić, „Izbori u Hrvatskoj 1990 - elektoralnogeografska analiza odabranih primjera“, Hrvatski geografski glasnik, 53, br. 1, (1991), 95-108; „Izbori za zastupnike u Hrvatski sabor (22.04.1990.)“, Državno izborno povjerenstvo Republike Hrvatske, https://www.izbori.hr/arhiva-izbora/\#/app/parlament-1990 (accessed 14. 2. 2021); Matevž Krivic, „Izbori u Sloveniji 1990“, Politička misao, 27, br. 2, (1990), 11-28; Ivica (Ivo) Lučić, Uzroci rata: Bosna i Hercegovina od 1980. do 1992. godine (Zagreb: Despot infinitus, 2013), 288; Radivoje Jovović, „Reformom izbornog sistema ka konsolidaciji demokratije“, in: Partije i izbori u Srbiji - 20 godina, ed. Slaviša Orlović (Beograd: Friedrich Ebert Stiftung; Fakultet političkih nauka - Centar za demokratiju, 2011), 274; Etem Aziri, „Izborni sistemi i izbori u Republici Makedoniji: prošlost, sadašnjost i izazovi za budućnost“", Političke perspektive, 3, br. 1, (2013), 7-21.

42 Nenad Dimitrijević, „Legitimiranje idealima - Značenje kategorije legitimiteta u socijalističkim društvima“", Politička misao, 26, br. 4, (1989), 68.

${ }^{43}$ S. Flere and R. Klanjšek, "What Typological Appellation is Suitable for Tito's Yugoslavia", 239.

${ }^{44}$ S. Flere and R. Klanjšek, "Was Tito’s Yugoslavia Totalitarian?”, 237. 
traces of totalitarianism after the mid-1960s? If yes, how does one explain these "sparkles" of totalitarianism, and how do they manifest when examining the regime's nature? Unfortunately, Flere and Klanjšek remain silent on this issue.

On the other hand, we claim that the three fundamental components of the communist rule remained intact after the 1960s: (i) the already mentioned repressive apparatus of the SDB and the police; (ii) Tito's role and position, and consequently that of the LCY; (iii) the individual and the policy of political and social indoctrination/education. We already discussed the SDB and the repressive apparatus at length, both in our response and in this text. We argued that the SDB remained the fundamental institution of the repressive apparatus. Despite the tensions and disagreements that occurred from time to time, the organization's role and its domain were rarely questioned, while its purpose was never altered. As for the role of Tito, it is enough to say that Tito himself became a constitutional category, where it was stated that his mandate as president could be without any limitations. ${ }^{45}$ To our knowledge, not even Stalin considered himself to be of such merit and importance that he should become a constitutional category worthy of inserting himself into the Soviet Constitution of 1936.

Traces of this totalitarian experiment can also be found in the analysis of the correlation between society and the individual. Let us consider the Pioneer Youth Organization and its role and purpose. Becoming a member of the Pioneer Alliance of Yugoslavia, or Tito's pioneers, as often referred to, presented the first and mandatory step for all first-grade elementary school pupils in becoming the new socialist man/woman. The ceremony envisioned children, age 6 or 7, wearing specially designed outfits and taking an oath to uphold brotherhood and unity and the ideas Tito had fought for. ${ }^{46}$ Despite the fact that the level of indoctrination gradually decreased following Tito's death, this mandatory ceremonial event represented the first step in children's lives marking their entrance into the world of communism, and remained as such until the last days of the communist rule. In fact, Tito's regime never abandoned the idea to mold the new socialist/communist man/woman. On the contrary, during the 1970s the ideological pressure grew, and the evidence for this can be found in the fact that the LCY leadership made a political decision to introduce Marxism as a subject in high schools and universities.

These tendencies of a more ideologically based education came to the forefront during the Tenth Congress of the LCY in 1974 when the "Resolution on the Tasks of the League of Communists of Yugoslavia in the Socialist SelfManagement Transformation of Upbringing and Education" (Rezolucija o zadacima Saveza komunista Jugoslavije u socijalističkom samoupravnom preobražaju odgoja i obrazovanja) was adopted. ${ }^{47}$ With it, the LCY initiated a

${ }^{45}$ „Ustav Socijalističke Federativne Republike Jugoslavije“, Službeni list SFRJ, 9/1974, Article 333.

${ }^{46}$ Igor Duda, Danas kada postajem pionir: djetinjstvo i ideologija jugoslavenskoga socijalizma (Zagreb: Srednja Europa, 2015), 126-134.

${ }^{47}$ Deseti kongres Saveza komunista Jugoslavije: dokumenti (Beograd: Izdavački centar Komunist, 1974), 279-289. 
new, hitherto most radical educational reform in Tito's Yugoslavia, especially concerning high school education. ${ }^{48}$ The resolution itself stated that "with the goal of achieving radical changes, all educators and pedagogues must act in unison in the following directions: to make sure that Marxism, as the ideology of the LCY and the scientific basis for building a socialist self-management society, is the ideological foundation for all the activities concerning education and upbringing." 49 Furthermore, the resolution stated that Marxism "is the basis of our entire education and upbringing" and as such "presents an obligation for all educators to be antagonistic and critical toward any non-scientific, antiMarxist theories, ideas, or ideologies that are foreign to socialist selfmanagement, as well as toward their proponents."50

The basic tenets of this resolution were further confirmed at the Eleventh Congress of the LCY in 1978, ${ }^{51}$ and as such served as a basis for future laws concerning upbringing and education. A new Law on Upbringing and Elementary Education was adopted in SR Croatia in late 1979, which, among its key purposes, affirms the development of "noble characteristics of a socialist persona." 52 Similarly, the Law on Vocation-Oriented Education was enacted in 1982, emphasizing that one of the tasks of vocational education was the "embracement of the Marxist worldview and values of a socialist self-management society." $"$ All of the above was not an entirely new perspective concerning the ideas of communist education in Tito's Yugoslavia. In fact, from the mid-1970s, high school pupils had mandatory subjects "The Basics of Marxism" (Osnove marksizma) and "Theory and Practice of Self-Management Socialism" (Teorija i praksa samoupravnog socijalizma), whose goals, according to the curriculum, were "for students to comprehend the meaning, values, and importance of Marxism as a system of thought and worldview, and to adopt it as their own system of thought and worldview." mine what students should learn, but also how they should think and act. The 1974 reform, which introduced obligatory courses in "Marxism" with the intention of developing "Marxist thought" among teachers and students, was the

\footnotetext{
${ }^{48}$ Slobodanka Munivrana-Hrženjak, „Politički faktor i usmjereno obrazovanje (na primjeru SR Hrvatske)“ (magistarski rad, Sveučilište u Zagrebu, Fakultet političkih nauka, 1991), 40-41.

${ }^{49}$ Deseti kongres Saveza komunista Jugoslavije, 283.

${ }^{50}$ Ibid.

${ }^{51}$ Jedanaesti kongres Saveza komunista Jugoslavije: dokumenti (Beograd: Izdavački centar Komunist, 1978), 364-380.

${ }_{52}$ Zakon o odgoju i osnovnom obrazovanju (Zagreb: Narodne novine, 1980), 6.

${ }^{53}$ Zakon o usmjerenom obrazovanju (Zagreb: Narodne novine, 1982), 10.

${ }^{54}$ „Osnove nastavnog plana i programa za srednjoškolsko obrazovanje u SR Hrvatskoj“, Prosvjetni vjesnik: službeni organ Republičkog sekretarijata za prosvjetu, kulturu i fizičku kulturu SR Hrvatske, 26, (1973), 159-160. Also see: Nataša Radiković, „Povijesni sadržaji u udžbenicima za predmete Osnove marksizma i Teorija i praksa samoupravnog socijalizma: teme, interpretacije, značenja“ (diplomski rad, Sveučilište u Zagrebu, Filozofski fakultet, Odsjek za povijest, 2015), 17. In the mid-1980s, the two subjects were joined into subject "Marxism and Socialist Self-management". Joco Marjanović, Gajo Sekulić, Marksizam i socijalističko samoupravljanje: udžbenik za I razred usmjerenog obrazovanja, 4. izd. (Sarajevo: Svjetlost, 1983).
} 
result of an "ideological offensive of the LCY in its desire to transform society and people." 55 According to Munivrana-Hrženjak, this was nothing but an instrumentalization of Marxism for political purposes, since its transformation into official ideology in education served to settle accounts with advocates of different political or ideological opinions. ${ }^{56}$

Secondly, the "indications" that Flere and Klanjšek speak of are precisely those aspects that we have marked as presenting the dynamic within the totalitarian experiment, which we deemed essential in the development of the communist regime of Tito's Yugoslavia. After all, as we quoted in our response, "no one set out to create what actually resulted, no one knew what totalitarianism was - because it was just coming into existence for the first time." 57 Therefore, these and other occurring changes in no way challenged or altered the fundamental tendencies or the idea of the Communist Party, nor the nature of its regime, which was to impose and have total control over political and social life in Yugoslavia, which all remained an essential part of the communist rule in Tito's Yugoslavia. The dynamic of changes that occurred in the 1960s brought about little changes in this sense. Flere and Klanjšek again emphasize the reforms initiated in the 1960s as proof that the communist rule changed significantly and that therefore, as of this period, Tito's Yugoslavia could not be considered a totalitarian regime. However, such a view would imply that the reforms initiated in the 1960s fundamentally changed the nature of the regime and its political and institutional structure as well and that these changes lasted until the regime's end. This was hardly the case. At the beginning of the 1970s, the atmosphere of "liberalization" and the weakening of the repressive apparatus came to an abrupt end. In SR Croatia, Tito and his close associates removed the reformist party members, with similar scenarios occurring in SR Serbia and SR Slovenia. This was a period of increased police and SDB repression, despite the fact that the communist authorities denied the existence of political prisoners. In fact, during the 1970s and 1980s, Tito's Yugoslavia had the highest number of political prisoners at that time in Europe, relative to its population. For example, in 1972, the Public Prosecutor's Office of the SR Croatia issued 2,378 criminal proceedings, of which the majority in question concerned the issue of the socalled verbal delict. ${ }^{58}$

As for the question of political pluralism, Flere and Klanjšek state that it was "in the form of republic interaction and not along in the Westminster model." 59 The political pluralism that they speak of relates only to the dynamics and

${ }^{55}$ S. Munivrana-Hrženjak, „Politički faktor i usmjereno obrazovanje“, 43-44.

${ }^{56}$ Ibid., 50-52.

${ }^{57}$ D. D. Roberts, The Totalitarian Experiment in Twentieth Century Europe, 17.

${ }^{58}$ HR-HDA-1220, CK SKH, Predsjednik CK SKH, ONO i DSZ, box. 13, 01-1, strogo povjerljivo $521 / 1,1979$, PCK SKJ, „Informacija o nekim pitanjima kretanja političkog kriminala, mestu i ulozi pravosudnih organa na njegovom suzbijanju i kadrovskoj $i$ organizacijskoj osposobljenosti ovih organa za zadatke u uslovima krizne situacije i u ratu", 1 .

59 S. Flere and R. Klanjšek, "What Typological Appellation is Suitable for Tito's Yugoslavia", 239. 
relations of political protagonists within the League of Communists of Yugoslavia, its republic branches, and their institutions. As such, this pluralism was not intended for all citizens of Yugoslavia but rather for those who belonged to the governing communist political structures, whose political, social, or economic decisions were seen as impervious and not liable to any outside criticism. We find that to name the internal relations between the communist leadership of the socialist republics, who all belonged to the LCY as their umbrella organization and were under the direct political power of Josip Broz Tito, as political pluralism - is wrong.

\section{Yugoslav Foreign Policy}

In their section "Other Issues" Flere and Klanjšek claim that we are wrong when stating that "The SRC [Socialist Republic of Croatia] never had a ministry (secretariat) of foreign affairs." To support their claim, they state that the "Socialist Republic of Croatia adopted a law in 1977 establishing a republic committee for international liaisons, a euphemism for a foreign service, but also that this committee continued activities which had previously been carried out by a body with a less illustrious title 'professional service of the council of the executive council for foreign relations." 60 It is correct that the SRC did have such a republic-level committee (republički komitet), however, to claim that it stood on equal grounds as a ministry is not true. Even more so, to claim that its official nomination was a euphemism for a ministry is even more astonishing since the prerogatives to conduct foreign affairs were possessed by the ministry (sekretarijat) on the federal level, and any actions on a lower level had to coordinate with it. This is clearly stated in article 2 and 3 of the Law on the Republic Committee of Foreign Relations with foreign countries where it states that: "The Committee, within the framework of the determined unified foreign policy of the Socialist Federative Republic of Yugoslavia and international contracts, deliberates questions that are of significance for the conduct of determined politics" (Article 2). Article 3 stipulates that "In questions of significance with regards to the conduct of determined policies, the execution of laws and other regulations and acts, as well as international agreements, the Committee cooperates with the Federal Secretariat for Foreign Affairs as well as with other federal organs."61 Thus, the role of the Republic's Committee was not to create and engage in foreign policy independently but rather to conduct and consult regarding the determined policies on the Republic's territory. The only example that could vaguely resemble this was Croatian (and Slovenian) participation in the Working Community of Cantons, Provinces, Counties, Regions and Republics in the Eastern Alps Area, established in Venice in November of 1978. The purpose of the Working Community was to discuss and coordinate regional ques-

\footnotetext{
${ }^{60}$ Ibid., 240.
}

${ }^{61}$ „Zakon o republičkom komitetu za odnose s inozemstvom“, Narodne novine: službeni list SRH, 31/1977. 
tions of transport, energy transfer, cultural cooperation, tourism, environment, and certain other sections of the economy. Nevertheless, the fact that Croatia and Slovenia participated in this working group does not imply that they had their own independent foreign policy. In fact, in order for them to participate they had to have the approval of the federal government and its bodies, since the SFRY conducted a unified foreign policy. ${ }^{62}$

Thus, what existed was a unified foreign policy in Tito's Yugoslavia and not a foreign policy conducted by the six republics and two autonomous provinces, as Flere and Klanjšek would like to believe. While it is true that during the late 1960s and early 1970s the republics gained a broader consent, even in the sense of a more active participation on the international level, these never implied, nor was its purpose to achieve, independent republic ministries for foreign affairs. Thus, as long as the communist regime ruled, Croatia, as a republic, never had its own ministry/secretariat for foreign affairs, nor did it possess an international subject's autonomy, and the same applies to the other republics as well. In fact, it was dangerous to promote such ideas of autonomous international activities at the beginning of the 1970s. This is best exemplified by the arrest of Hrvoje Šošić in 1971. It was Šošić who, during a student meeting in October of 1971, put forward the idea that the SR of Croatia should ask for membership in the United Nations (UN). This would not constitute precedence since such cases existed at the time: Ukraine and Belarus, which, although members of the USSR, were also members of the United Nations. However, due to this idea, as well as his suggestion that the SR of Croatia should also have its own national bank, which could independently borrow money internationally, Šošić was arrested in January of 1972 and sentenced to two years in prison and a two-year ban on public appearances. ${ }^{63}$

In the sphere of foreign policy, the role of the republic and provincial assemblies was secondary, while on the federal level even the role of Federal Assembly of the SFRY was marginal in this question. ${ }^{64}$ When it comes to foreign policy in Tito's era, the most crucial role was played by Tito himself, followed by the three institutions on the level of the federation: the Federal Secretariat for Foreign Affairs, the leadership of the LCY, and Tito's cabinet. ${ }^{65}$

So, just to be clear, the SR of Croatia did not have a ministry of foreign affairs, nor were the Yugoslav republics internationally recognized subjects in international politics. And even if it had been so, as Flere and Klanjšek would have their readers believe, this once again tells us little or nothing about the nature of Tito's regime and its totalitarian character. We emphasize that federal-

${ }^{62}$ Tvrtko Jakovina, „Hrvatska izlazi u svijet: Hrvatska/Jugoslavija u svjetskoj politici 19451991", in: Hrvatska politika u XX. stoljeću, ed. Ljubomir Antić (Zagreb: Matica hrvatska, 2006), 378-381.

${ }^{63}$ Mato Artuković, „Presude hrvatskim intelektualcima 1972.“, in: Hrvatska i Hrvatsko proljeće 1971.: Zbornik radova, ed. Igor Zidić (Zagreb: Matica hrvatska, 2017), 250-252.

${ }^{64}$ Dejan Jović, „Analiza vanjske politike socijalističke Jugoslavije: akteri i strukture“, Anali Hrvatskog politološkog društva, 14, no. 1, (2017), 164.

${ }^{65}$ Ibid., 166. 
ism as a state system bears no significant meaning in this, even though Flere and Klanjšek wish to present it as significant evidence for the non-existence of totalitarianism in Tito's Yugoslavia.

\section{Conclusion}

To conclude, we find it important to mention several vital aspects that need to be taken into consideration when discussing the nature of Tito's Yugoslavia. Namely: (i) citizens were unable to cast their votes in free elections and were thus denied the opportunity to have any impact on the political, social, or economic politics that influenced their lives; (ii) the only "legitimate" way to exert individual influence in the political, social or economic area was to conform to and accept the prevalent idea of the communist interpretation of Marxism, the communist worldview, and the political power of the communist party; (iii) any attempt to openly oppose and/or criticize the regime was met with repercussions and punishment; (iv) any such activities were suppressed by the state apparatus on the republic and federal levels; (v) every individual or group active within the political structures was aware of Tito's power to remove whomever he and his closest associates deemed "dangerous" or "destructive" elements; (vi) the communist leadership in the federal republics was faced with forceful removal and suppression when their policies were evaluated as noncompliant or dangerous; (vii) from an early age, individuals were immersed into the collective where they had to learn what it meant to be a "proper" and "respected" citizen. All these aspects were in force until the breakdown of Tito's Yugoslavia. In conclusion, the occurring changes and dynamics never altered this totalitarian experiment's core idea and its primary goal: to establish a socialist/communist society ruled by one party, the LCY, supervised by its police, secret service, army, and guided by a single ideological framework of the communist interpretation of Marxism. 


\section{REFERENCES}

- Amnesty International Report 1990. London: Amnesty International Publications, 1990.

- Artuković, Mato. „Presude hrvatskim intelektualcima 1972“. In: Hrvatska $i$ Hrvatsko proljeće 1971.: Zbornik radova, ed. Igor Zidić, 215-261. Zagreb: Matica hrvatska, 2017.

- Axboe Nielsen, Christian. „Decentralizacija organa unutarnjih poslova u SR Hrvatskoj“. Politička misao, 57, br. 3, (2020), 174-191. https://doi.org/10. 20901/pm.57.3.07

- Aziri, Etem. „Izborni sistemi i izbori u Republici Makedoniji: prošlost, sadašnjost i izazovi za budućnost“". Političke perspektive, 3, br. 1, (2013), 7-21.

- Deseti kongres Saveza komunista Jugoslavije: dokumenti. Beograd: Izdavački centar Komunist, 1974.

- Dimitrijević, Nenad. „Legitimiranje idealima - Značenje kategorije legitimiteta u socijalističkim društvima“. Politička misao, 26, br. 4, (1989), 56-70.

- Duda, Igor. Danas kada postajem pionir: djetinjstvo $i$ ideologija jugoslavenskoga socijalizma. Zagreb: Srednja Europa, 2015.

- Flere Sergej, and Rudi Klanjšek. "Was Tito's Yugoslavia totalitarian?". Communist and Post-Communist Studies, 47, (2014), 237-245. https://doi.org/10. 1016/j.postcomstud.2014.04.009

- Flere Sergej, and Rudi Klanjšek. "What Typological Appellation is Suitable for Tito's Yugoslavia: Response to Mihaljević and Miljan". Istorija 20. veka, 38, br. 2, (2020), 231-244. https://doi.org/10.29362/ist20veka.2020.2.fle.231-244

- „Izbori za zastupnike u Hrvatski sabor (22.04.1990.)“. Državno izborno povjerenstvo Republike Hrvatske. https://www.izbori.hr/arhiva-izbora/\#/app/ parlament-1990. (accessed 14. 2. 2021).

- Jakovina, Tvrtko. „Hrvatska izlazi u svijet: Hrvatska/Jugoslavija u svjetskoj politici 1945-1991“. In: Hrvatska politika u XX. stoljeću, ed. Ljubomir Antić, 337-388. Zagreb: Matica hrvatska, 2006.

- Jedanaesti kongres Saveza komunista Jugoslavije: dokumenti. Beograd: Izdavački centar Komunist, 1978.

- Jović, Dejan. „Analiza vanjske politike socijalističke Jugoslavije: akteri i strukture“. Anali Hrvatskog politološkog društva, 14, br. 1, (2017), 147-169. https://doi.org/10.20901/an.14.07

- Jovović, Radivoje. „Reformom izbornog sistema ka konsolidaciji demokratije“. In: Partije i izbori u Srbiji - 20 godina, ed. Slaviša Orlović, 271-282. Beograd: Friedrich Ebert Stiftung; Fakultet političkih nauka Centar za demokratiju, 2011.

- Kasapović, Mirjana. „Izborni modeli i politički sustav“. Politička misao, 29, br. 2, (1992), 12-22.

- Klemenčić, Mladen. „Izbori u Hrvatskoj 1990 - elektoralnogeografska analiza odabranih primjera“. Hrvatski geografski glasnik, 53, br. 1, (1991), 95-108. 
- Krivic, Matevž. „Izbori u Sloveniji 1990“. Politička misao, 27, br. 2, (1990), $11-28$.

- Lučić, Ivica (Ivo). Uzroci rata: Bosna i Hercegovina od 1980. do 1992. godine. Zagreb: Despot infinitus, 2013.

- Marjanović Joco, and Gajo Sekulić. Marksizam i socijalističko samoupravljanje: udžbenik za I razred usmjerenog obrazovanja, 4th ed. Sarajevo: Svjetlost, 1983.

- Mihaljević Josip, and Goran Miljan. "Was Tito's Yugoslavia Not Totalitarian?". Istorija 20. veka, 38, no.1, (2020), 223-248.

https://doi.org/10.29362/ist20veka.2020.1.mih.223-248

- Mujadžević, Dino. Bakarić - politička biografija. Zagreb: Hrvatski institut za povijest - Podružnica za povijest Slavonije, Srijema i Baranje, 2011.

- Munivrana-Hrženjak, Slobodanka. „Politički faktor i usmjereno obrazovanje (na primjeru SR Hrvatske)“. Magistarski rad, Sveučilište u Zagrebu, Fakultet političkih nauka, 1991.

- „Osnove nastavnog plana i programa za srednjoškolsko obrazovanje u SR Hrvatskoj“. Prosvjetni vjesnik: službeni organ Republičkog sekretarijata za prosvjetu, kulturu i fizičku kulturu SR Hrvatske, 26, (1973), 152-183.

- Radiković, Nataša. „Povijesni sadržaji u udžbenicima za predmete Osnove marksizma i Teorija i praksa samoupravnog socijalizma: teme, interpretacije, značenja“. Diplomski rad, Sveučilište u Zagrebu, Filozofski fakultet, Odsjek za povijest, 2015.

- Roberts, David D. The Totalitarian Experiment in Twentieth Century Europe: Understanding the Poverty of Great Politics. New York - London: Routledge, 2006. https://doi.org/10.4324/9780203087848

- Štih Peter, Vasko Simoniti and Peter Vodopivec. A Slovene history: society politics - culture. Ljubljana: Inštitut za novejšo zgodovino, 2008. http://hdl.handle.net/11686/2250 (accessed 14. 2. 2021).

- Vukušić, Bože. „Predgovor: Metodologija rada Udbe na primjeru Vice Vukojevića“. In: Dosje 240271: Udbin dosje o Vici Vukojeviću, ed. Bruna Esih, pp. XVII-XXXIX. Zagreb: Udruga Hrvatski križni put, 2015.

- Yugoslavia: Prisoners of Conscience: Amnesty International Report. London: Amnesty International Publications, 1981. 
JOSIP MIHALJEVIĆ, PhD, Research Fellow

Croatian Institute of History

Zagreb, Republic of Croatia

josip@isp.hr

GORAN MILJAN, PhD, Researcher

Hugo Valentin-centrum, Uppsala University

Uppsala, Kingdom of Sweden

goran.miljan@valentin.uu.se

\begin{abstract}
"HUMANIST" MARXISM AND THE COMMUNIST REGIME WITH "SPARKLES" OF TOTALITARIANISM: THE YUGOSLAV COMMUNIST TOTALITARIAN EXPERIMENT (RESPONSE TO FLERE AND KLANJŠEK)
\end{abstract}

\title{
Summary
}

This paper is a response to the article "What Typological Appellation is Suitable for Tito's Yugoslavia" published by Sergej Flere and Rudi Klanjšek in Istorija 20. veka, in which the two authors responded to our criticism of their previously published article. Unfortunately, the two authors saw our paper as an attack, either on them personally or on their academic merits and research, which was neither the aim nor desire of our response. In this article, we contest and dispute the arguments and claims made by Flere and Klanjšek, and especially their attempt to discredit us by actually fabricating our words. Instead of engaging in an open academic debate, Flere and Klanjšek attempt to derail this debate from its core by focusing solely on some minor mistakes, thus trying to show that we were superficial and counter-factual. Our decision to reflect on some of their statements served the purpose of demonstrating that Flere and Klanjšek's response was far from an expected academic debate. In fact, in their response Flere and Klanjšek avoided addressing the crucial issues pertaining to the question of totalitarianism and the occurring dynamics of the Yugoslav communists' idea on how to structure, rule, and supervise Yugoslav society. On the contrary, they decided to resolve this issue by introducing new views on the subject and new "solutions," which deliver little substance to the key issues of this debate. However, our article reveals that the majority of their arguments is questionable or can be outright refuted by taking into consideration contemporary views on totalitarianism and the existing empirical data. This is evident with regard to the questions of historical dynamism, secret services, unified foreign policy, the role and position of the individual, Tito's role and power, and Flere and Klanjšek's distorted view of communist legitimacy. In our conclusion we point to the key aspects that need to be taken into consideration when discussing the nature of Tito's Yugoslavia. Namely: (i) citizens were unable to cast their votes in free elections and were thus denied the opportunity to 
have any impact on the political, social, or economic politics that influenced their lives; (ii) the only "legitimate" way to exert individual influence in the political, social or economic area was to conform to and accept the prevalent idea of the communist interpretation of Marxism, the communist worldview, and the political power of the communist party; (iii) any attempt to openly oppose and/or criticize the regime was met with repercussions and punishment; (iv) any such activities were suppressed by the state apparatus on the republic and federal levels; (v) every individual or group active within the political structures was aware of Tito's power to remove whomever he and his closest associates deemed "dangerous" or "destructive" elements; (vi) the communist leadership in the federal republics was faced with forceful removal and suppression when their policies were evaluated as non-compliant or dangerous; (vii) from an early age, individuals were immersed into the collective where they had to learn what it meant to be a "proper" and "respected" citizen. All these aspects were in force until the breakdown of Tito's Yugoslavia. In conclusion, the occurring changes and dynamics never altered this totalitarian experiment's core idea and its primary goal: to establish a socialist/communist society ruled by one party, the LCY, supervised by its police, secret service, army, and guided by a single ideological framework of the communist interpretation of Marxism.

KEYWORDS: Totalitarianism, Yugoslavia, Communism, Federalism, Josip Broz Tito, Individual 